\title{
Morphological and molecular characterization of the toxic dinoflagellate Ostreopsis cf. ovata (Gonyaulacales: Dinophyceae) from Brazil (South Atlantic Ocean)
}

Fernando Gómez ${ }^{1}$, Dajun Qiu², Rubens M. Lopes ${ }^{3} \&$ Senjie Lin ${ }^{4,5}$

1. Carmen Campos Panisse, 3; E-11500 Puerto de Santa María, Spain; fernando.gomez@fitoplancton.com

2. CAS Key Laboratory of Tropical Marine Bio-resources and Ecology, South China Sea Institute of Oceanology, Chinese Academy of Science, Guangzhou, China; djqiu@scsio.ac.cn

3. Laboratory of Plankton Systems, Oceanographic Institute, University of São Paulo, Praça do Oceanográfico 191, São Paulo, SP 05508-120, Brazil; rubens@usp.br

4. Department of Marine Sciences, University of Connecticut, Groton, Connecticut, United States of America; senjie.lin@uconn.edu

5. Marine Biodiversity and Global Change Research Center and State Key Laboratory of Marine Environmental Science, Xiamen University, Xiamen, China; senjie.lin@xmu.edu.cn

Received 23-XI-2016. Corrected 11-IV-2017. Accepted 11-V-2017.

\begin{abstract}
Ostreopsis cf. ovata is a toxic epiphytic dinoflagellate widely distributed in warm waters that often co-occur with species of the genera Coolia, Fukuyoa, Gambierdiscus and Prorocentrum. We investigated a strain isolated from the coast of Ubatuba, Brazil (Southwest Atlantic Ocean) by light and epifluorescence microscopies; we also report molecular data based on the LSU rDNA and ITS markers. Cells were 35-65 $\mu \mathrm{m}$ in the dorso-ventral diameter and 20-40 $\mu \mathrm{m}$ wide. We obtained the sequence of a $\sim 1900$ base pair region of the rRNA gene cistron. In the LSU rDNA phylogeny, the sequences under the names $O$. ovata and $O$. cf. ovata branched into three clades. The ITS marker showed greater resolving power and the sequences of O. ovata/O. cf. ovata split into five clades. Our ITS sequence branched in a clade with sequences of strains from the Mediterranean Sea, European Atlantic coasts, subtropical NE Atlantic, other sequences from Brazil at Rio de Janeiro, and a few sequences from Japan. The cell dimensions and thecal plate arrangement were under the variability range reported in other ocean regions. Our observations confirm $O$. cf. ovata as the most commonly recorded species of Ostreopsis in the SW Atlantic Ocean. Ostreopsis cf. ovata co-occurred with Coolia malayensis in Brazil and Asia, but it has been commonly reported from the Mediterranean Sea, where C. malayensis has not yet been recorded; while Coolia malayensis has been reported from the Caribbean Sea, but not $O$. ovata. With the current knowledge, it is difficult to understand the factors that determine the biogeography of the tropical epiphytic dinoflagellates. Rev. Biol. Trop. 65 (3): 1022-1032. Epub 2017 September 01.
\end{abstract}

Key words: benthic Dinophyta, epiphytic microalgae, harmful algal blooms, red tides, South Atlantic Ocean, toxic Dinoflagellata.

The genus Ostreopsis Johannes Schmidt comprises species of potentially toxic epiphytic dinoflagellates, which often co-occur with other species of the genera Gambierdiscus Adachi \& Fukuyo, Coolia Meunier and Prorocentrum Ehrenberg in warm and temperate oceans (Ashton, Tosteson, \& Tosteson, 2003; HernándezBecerril \& Almazán-Becerril, 2004; Tosteson, 2004; Delgado, Lechuga-Devéze, Popowski, Troccoli, \& Salinas, 2006). The type species, $O$. siamensis Johannes Schmidt was described from the Gulf of Thailand (Schmidt, 1901). Fukuyo (1981) re-described O. siamensis, and described the new species $O$. ovata Fukuyo and O. lenticularis Fukuyo. Additional species were $O$. belizeana M.A. Faust, O. caribbeana M.A. Faust, O. fattorussoi Accoroni, Romagnoli \& Totti, O. heptagona D.R. Norris, J.W. Bomber \& Balech, O. labens M.A. Faust \& S.L. Morton, O. marina M.A. Faust and O. mascarenensis J.P. Quod (Norris, Bomber, \& Balech, 1985; Quod, 1994; Faust \& Morton, 1995; Faust, 
1999; Accoroni et al., 2017). Other ecologically related genera such as Gambierdiscus or Coolia have increased the number of species in the last decade, due to the emergence of molecular data. In contrast, the number of species of Ostreopsis has remained static between 1999 and 2016. This situation is attributable to some confusion in the diagnostic characters for the delimitation of the known species due to plasticity in its morphology (see review in Parsons et al., 2012). Schmidt (1901) described $O$. siamensis based on two illustrations, elongated and round cells. Fukuyo (1981) re-described $O$. siamensis and ascribed it to Schmidt's round cell, and the elongated cells were described as the new species O. lenticularis (Fukuyo, 1981). Ostreopsis lenticularis was distinguished from $O$. siamensis by lacking body undulation and having fine pores densely scattered on the thecal plates in addition to the larger pores found on both species. Fukuyo (1981) also described $O$. ovata as distinguishable from the other two species by having a more ovoid shape and smaller size. These diagnostic characters are not stable and the lack of genetic data for the holotype specimens lead to the use of these names as $O$. cf. ovata or $O$. cf. siamensis until accurate morphological data and genetic sequences gathered from the type localities re-defines each species (Penna et al., 2005, 2010). Sequences of several strains $O$. cf. ovata isolated in 2000 in a single location at Rio de Janeiro, Brazil, branched with sequences from the Mediterranean Sea and the temperate and subtropical NE Atlantic at Madeira and Canary Islands, confirming the wide distribution of this species (Penna et al., 2005, 2010; David, Laza-Martínez, Miguel, \& Orive, 2013). Nascimento, França, Gonçalves, and Ferreira (2012b) and Nascimento, Corrêa, Menezes, Varela, Paredes, and Morris (2012a) provided additional molecular data, and confirmed the toxicity $O$. cf. ovata from Brazil. However, the plate arrangement of $O$. cf. ovata in the South Atlantic Ocean has not been documented, and existing molecular information only came from strains isolated in Rio de Janeiro.
The present study reports molecular data based on the LSU rDNA and ITS markers, and for the first time illustrated the plate arrangement of $O$. cf. ovata from the South Atlantic Ocean. This study provides data needed for better understanding on the distribution of Ostreopsis spp. in the world ocean and on the variations in the morphology and DNA sequences.

\section{MATERIALS AND METHODS}

Sampling, isolation, culturing and light microscopy: Cells of Ostreopsis were observed from the coasts of São Paulo State, Brazil, in the South Atlantic Ocean. Isolation was carried out on 18 December 2013 during the low tide around the pier of the Marine Station of the University of São Paulo at Ubatuba (2330’3.16" S - 457'6.78” W). Macroalgae were collected from rocky surfaces during the low tide $(<1 \mathrm{~m}$ depth), placed into a bottle with ambient water and stirred vigorously. The gross particles were removed through a $200 \mu \mathrm{m}$ mesh filter.

In the laboratory, the bottle sample was stirred, and the suspension was let to settle in a composite settling chamber. Epiphytic cells were examined with an inverted microscope Nikon TS-100 (Nikon, Tokyo, Japan) and photographed with a digital camera mounted on the microscope's eyepiece (Cyber-shot DSCW300, Sony, Tokyo, Japan).

A single cell of Ostreopsis was isolated using a micropipette and placed in 24-well tissue culture plate with $0.2 \mu \mathrm{m}$-filtered seawater collected that day from the same locality, supplemented with $\mathrm{f} / 2$ medium without silicates. Two days later, the cells were placed into a 6-well tissue culture plate with $\mathrm{f} / 2$ medium made with filtered and sterilized seawater. Seawater was collected two kilometers offshore and in the laboratory, it was prefiltered through a Whatman GF/F glass filter $(\sim 0.7 \mu \mathrm{m})$, and subsequently passed through a Nuclepore polycarbonate filter $(0.2 \mu \mathrm{m})$. Borosilicate glass bottles partially filled with filtered seawater were covered with aluminum foil 
and autoclaved during 15 minutes at 1-2 bar pressure, and a temperature of $120{ }^{\circ} \mathrm{C}$. After one day, bottles were placed in the incubator for at least one day before use. The culture was incubated at $23{ }^{\circ} \mathrm{C}$, with $100 \mu \mathrm{mol}$ photons $\mathrm{m}^{-2} \cdot \mathrm{s}^{-1}$ from cool-white tubes; the photoperiod was 12:12 h L:D. The aliquots of the clonal culture $(2 \mathrm{~mL})$ were transferred to $50 \mathrm{~mL}$ polystyrene tissue culture flasks with $20 \mathrm{~mL}$ of culture medium and incubated under the same conditions. A volumen of $20 \mathrm{~mL}$ of fresh culture medium was added after two weeks. Aliquots of the culture were harvested during the first weeks for further observations with epifluorescence and confocal microscopes. After one month, cells with distorted shapes began to appear. The cells were fixed with $5 \%$ glutaraldehyde and kept in the refrigerator. Morphological studies used epifluorescence and confocal microscopes, fixed cells were transported to the University campus ( $\sim 250 \mathrm{~km}$ far away from the coastal laboratory). The fixed cells were stained with Fluorescent Brightener 28 (Sigma-Aldrich, St. Louis, MO, USA) (blue emission) and observed at $\times 1000$ magnification under an Olympus BX51 epifluorescence microscope equipped with an Olympus DP72 camera. Cells fixed with glutaraldehyde were also observed at $\times 630$ magnification with an inverted confocal microscope TCS SP8 AOBS (Leica, Wetzlar, Germany), after staining with Fluorescent Brightener 28. The nomenclature for the plate tabulation followed Gómez, Qiu, Lopes, and Lin (2015).

DNA extraction, PCR amplification of rRNA gene, and sequencing: By the use of the inverted microscope, cultured cells of Ostreopsis were micropipetted individually with a fine capillary into a clean chamber and washed several times in a series of drops of 0.2 $\mu \mathrm{m}$-filtered and sterilized seawater. Finally, a total of 50 cells were placed in a $0.2 \mathrm{~mL}$ Eppendorf tube filled with several drops of absolute ethanol. The sample was kept at room temperature in darkness during one year, until the molecular analysis could be performed. Prior to DNA extraction, the tubes were centrifuged for
$10 \mathrm{~min}$ at $10000 \mathrm{rpm}$ to settle the Ostreopsis cells, and the ethanol was aspirated. The cell pellet was resuspended in $100 \mu \mathrm{L}$ of DNA lysis buffer (0.1 M EDTA pH 8.0, $1 \%$ SDS, 200 $\mu$ g. $\mathrm{mL}^{-1}$ proteinase $\mathrm{K}$ ) and transferred into a $1.5 \mathrm{~mL}$ tube, and the original tube was washed with $100 \mu \mathrm{L}$ of DNA lysis buffer for four more times. Then, the resultant $0.5 \mathrm{~mL}$ was incubated for 48 hours at $55{ }^{\circ} \mathrm{C}$. DNA extraction and purification followed a previously reported protocol (Qiu, Huang, Liu, \& Lin, 2011). At the end of the extraction process, Ostreopsis DNA was eluted in $50 \mu \mathrm{L}$ of Tris- $\mathrm{HCl}$ solution. Next, $1 \mu \mathrm{L}$ of the extracted DNA was used in PCR with primers Dino1662F and 28SR2 to amplify a $\sim 1900$ base pair region of the rRNA gene cistron covering 3 ' end region of the SSU, the entire ITS, and partial 5' region of the LSU (3'end-SSU-ITS1-5.8S-ITS2-LSU) (Qiu, Huang, Liu, Zhang, \& Lin, 2013). The PCR amplifications were carried out in $25 \mu \mathrm{L}$ reaction volumes under thermocycling conditions, including a denaturing step of $94^{\circ} \mathrm{C}$ for $4 \mathrm{~min}$; 35 cycles of $94{ }^{\circ} \mathrm{C}$ for $30 \mathrm{~s}, 56{ }^{\circ} \mathrm{C}$ for $30 \mathrm{~s}, 72$ ${ }^{\circ} \mathrm{C}$ for $45 \mathrm{~s}$, and a final extension step of $72{ }^{\circ} \mathrm{C}$ for $10 \mathrm{~min}$. PCR products were resolved by agarose gel electrophoresis with the DL2000 DNA Ladder (TaKaRa Bio, Dalian, China), and the bands with expected sizes were excised in order to remove primer dimers. DNA was purified and directly sequenced as previously reported (Qiu et al., 2011).

Phylogenetic analyses: The DNA sequence was analyzed using Basic Local Search Tool (BLAST) against databases in GenBank. A total of 58 of LSU rDNA and 62 of ITS-5.8S-ITS2 hit sequences showing significant similarity to the sequences obtained in this study were retrieved from the databases. Combined sequences were aligned with ClustalW, using default parameters (Larkin et al., 2007), and obvious misalignments adjusted manually. The trimmed ITS-5.8S-ITS2 and D1-D2 LSU alignments were analyzed using ModelTest to select the most appropriate evolutionary model (Posada \& Crandall, 1998). The selected General Time Reversible model with gamma 
distribution was employed for Maximum Likelihood analysis using PhyML3.0 (Tamura, Stecher, Peterson, Filipski, \& Kumar, 2013). Categories of substitution rates were set at four, and other parameters were estimated based on the datasets. The proportion of invariable sites and the gamma shape parameter were 0.00 and 1.1064 for the LSU dataset, and 0.2546 and 4.3634 for ITS, respectively. The sequence (LSU rDNA and ITS) obtained in this study was deposited in GenBank under accession number KX781270.

\section{RESULTS}

Morphology: The wild cells from recently collected samples were oval to tear-shaped fully covered of brown pigments, and some cells showed a large red body (Fig. 1A, Fig. 1B, Fig. $1 \mathrm{C}$ and Fig. 1D). In apical-antapical view, the dorso-ventral diameter of wild cells ranged from 35 to $65 \mu \mathrm{m}$ with an average value of 55.1 $\mu \mathrm{m}$, and the transdiameter (width) ranged from
20 to $40 \mu \mathrm{m}$ with an average value $32.6 \mu \mathrm{m}$ $(\mathrm{n}=15)$. The average ratio between the dorsoventral axis and the transdiameter was 1.69. The cell dimensions of our cells and those from other ocean regions were compared in Table 1.

In the cultured cells, the apical pore complex (APC) plate was located on the dorsal side. It was about $8 \mu \mathrm{m}$ long and slightly curved, enclosed by the plate 2 ' and also touched apical plates 1 ', and 3 '. There were three apical plates (Fig. 1E, Fig. 1F, Fig. 1G, Fig. 1H, Fig 1I). The 1 ' plate occupied the center of the epitheca. It was hexagonal and touched the plates 2', 3', 1 ", 2", 6" and 7" (Fig. 1G, Fig. 1H, Fig. 1I). The plate 2' was elongated and the 3' plate was irregularly pentagonal in the dorso-central epitheca (Fig. 1G, Fig. 1H and Fig. 1I). There were seven precingular plates. Plates 1", 2", 3 ", 4 ", 5" and 7 " were irregularly quadrangular. The 1", 4", and 5 " plates were the smallest. The 2 " and 3 " plates were dorso-ventrally elongated. The 6" plate was pentagonal and the largest of the precingular series (Fig. 1F, Fig. $1 \mathrm{G}$, Fig. 1H and Fig. 1I).

TABLE 1

Morphometric gathering of cultured Ostreopsis ovata/O. cf. ovata data

\begin{tabular}{lccl}
\multicolumn{1}{c}{ Place } & DV & W & \\
Ubatuba, Brazil & $35-65$ & $20-40$ & This study \\
Saint Paul's Rocks, Brazil & $46-65$ & $27-46$ & Nascimento et al. (2012b) \\
Arraial do Cabo, Brazil & $40-65$ & $18-45$ & Nascimento et al. (2012a) \\
Tyrrhenian Sea, Mediterranean & $34-67$ & $25-40$ & Tognetto, Bellato, Moro, \& Andreoli (1995) \\
Adriatic Sea, Mediterranean & $42-59$ & $26-41$ & Monti, Minocci, Beron, \& Ivesa (2007) \\
Adriatic Sea, Mediterranean & $19-75$ & $12-60$ & Accoroni, Romagnoli, Pichierri, Colombo, \& Totti (2012) \\
Gulf of Naples, Mediterranean & $40-64$ & - & Rossi et al. (2010) \\
Gulf of Naples, Mediterranean & 48.3 & 33.3 & Scalco et al. (2012) \\
Western Mediterranean & $27-65$ & $19-57$ & Penna et al. (2005) \\
NW Mediterranean & $21-77$ & $15-51$ & Carnicer, Guallar, Andree, Diogène, \& Fernández-Tejedor (2015) \\
Aegen Sea, Mediterranean & $27-62$ & $13-48$ & Aligizaki \& Nikolaidis (2006) \\
Spain, Atlantic & $55-84$ & $30-62$ & David et al. (2013) \\
Kuwait, Indian Ocean & $48-72$ & $30-51$ & Al-Yamani \& Saburova (2010) \\
Russian Pacific & $36-60$ & $24-45$ & Selina \& Levchenko (2011) \\
Vietnam, Pacific & $50-55$ & $30-35$ & Larsen \& Nguyen (2004) \\
Malaysia, Pacific & $32-55$ & $22-39$ & Leaw, Lim, Ahmad, \& Usup (2001) \\
Ryukyu Is., tropical Pacific & $50-56$ & $25-35$ & Fukuyo (1981) \\
Japan, Pacific & $28.1 \pm 2.6$ & $20.8 \pm 3.3$ & Sato et al. (2011) \\
New Zealand, Pacific & $38-50$ & $25-35$ & Chang et al. (2000) \\
\hline & & &
\end{tabular}

Dorso-ventral diameter (DV) and transdiameter or width (W) in $\mu \mathrm{m}$. 


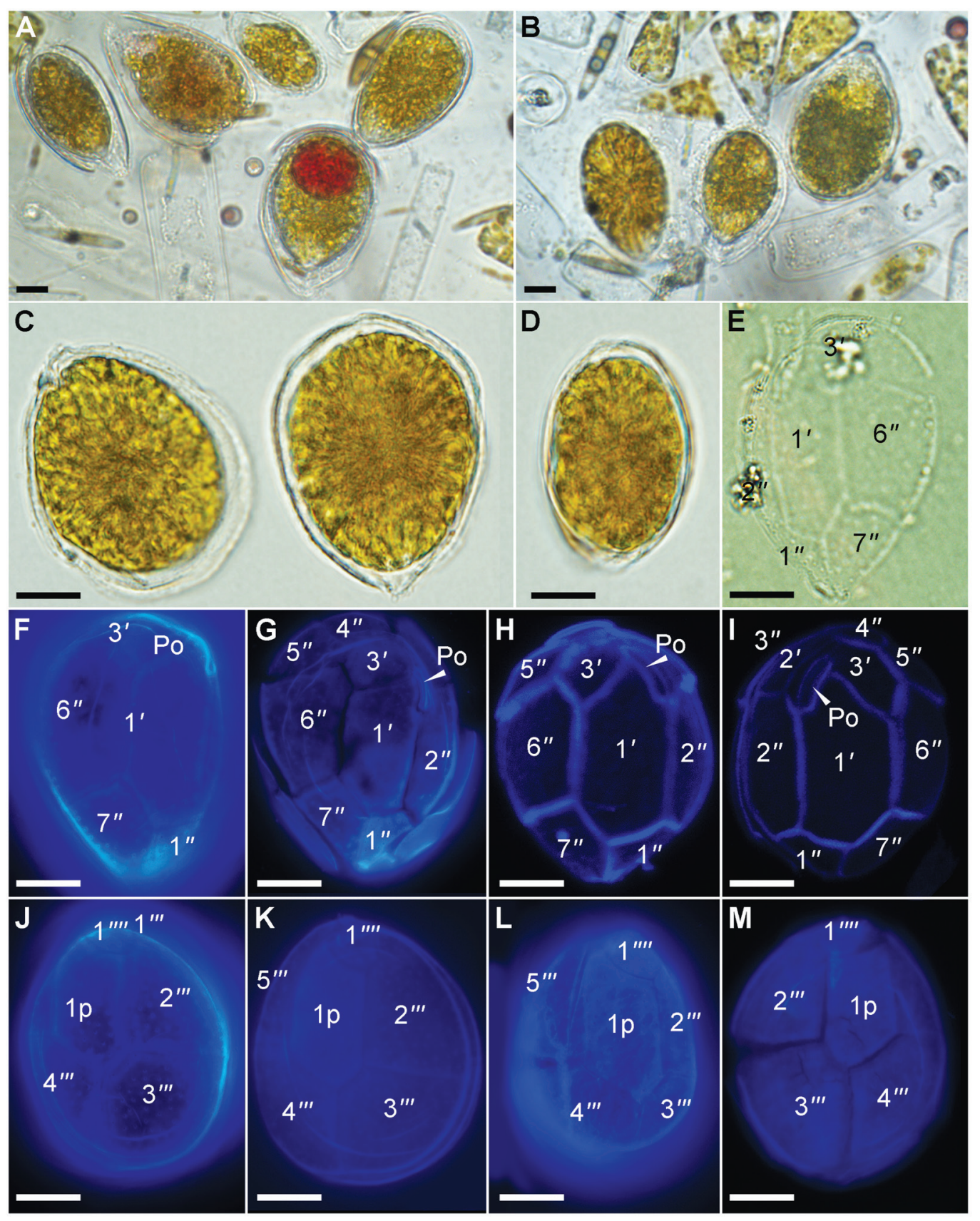

Fig. 1. Light micrographs of Ostreopsis cf. ovata from Ubatuba, São Paulo, Brazil; A-B. Recently collected wild cells; C-M. Cultured strain UBA-BR; A. Note the prominent red accumulation body; B. Note the size differences; C. Apical-antapical view; D. Lateral view; E. Empty epitheca; F-G. View of the epitheca of calcofluor stained cells under epifluorescence microscopy; H-I View of the epitheca with overlay images of confocal microscopy; J-M. View of the hypotheca of calcofluor stained cells under epifluorescence microscopy. Scale bar $=10 \mu \mathrm{m}$. 
In the hypotheca, there were five postcingular plates. Most of the hypotheca was occupied by the plates 2,", 3 ”, 4 "”, and a posterior intercalary plate (1p) (Fig. 1J, Fig. 1K, Fig. 1L, Fig. 1M). The 2"' plate was quadrangular and dorso-ventrally elongated. The 3 "' and 4 "' plates were quadrangular and extended for most of the dorsal half of the hypotheca. The 1"' plate much smaller than the other postcingular plates was difficult to observe. The 5 "' plate was oblong and irregularly triangular (Fig. 1K and Fig. 1L). The $1 \mathrm{p}$ plate (or alternatively interpreted as the second antapical plate, 2 ,"') was showed an elongated pentagonal shape. The first antapical plate was small, triangular and located between the plates 2 "' and $1 \mathrm{p}$ (Fig. $1 \mathrm{~J})$. The plate formula was Po, 3', 7', 5', $1 \mathrm{p}$, and 1 ,'” or alternatively Po, 4', 6", 5,", 2,"," The cell surface was smooth. The number

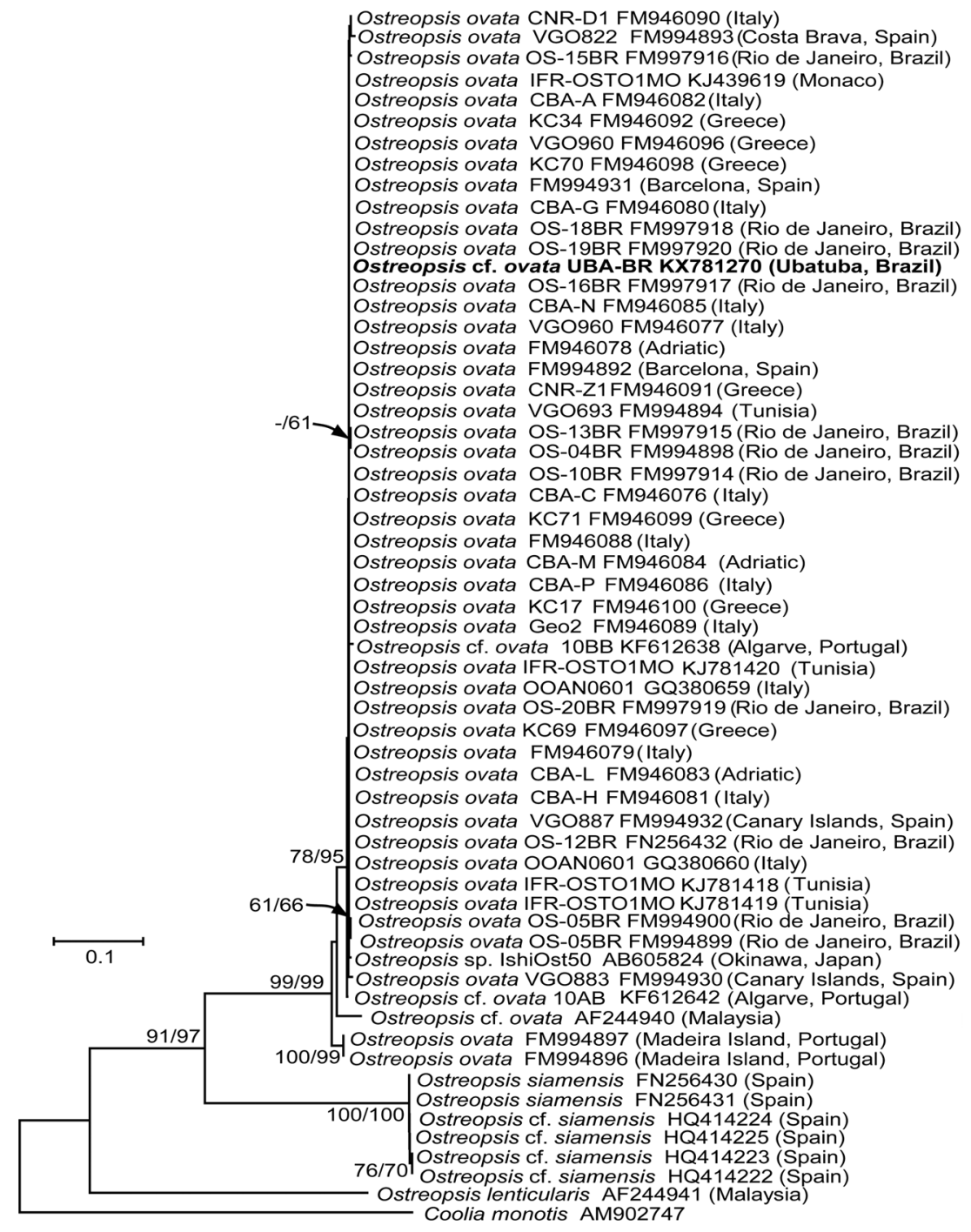

Fig. 2. Maximum likelihood tree of Ostreopsis spp. based on the LSU rDNA (D1-D2) sequences. The sequence obtained in this study is bold-typed. Support of nodes is based on bootstrap values of Maximum Likelihood (ML)/Neighbor Joining (NJ) methods with 1000 resamplings. Only values greater than 60 are shown. Coolia monotis was used as an outgroup. 
of large pores per $25 \mu \mathrm{m}^{2}$ of the thecal surface was 3-4 (Fig. 1J).

Molecular phylogeny: In the LSU rDNA phylogenetic tree, the sequences under the names Ostreopsis ovata and $O$. cf. ovata branched into three clades. The most basal clade contained two sequences from strains isolated at Madeira Island in the NE subtropical Atlantic Ocean. Other clade contained a sequence from Malaysia. Our new LSU rDNA sequence branched in the main clade together with sequences of strains from the Mediterranean Sea, European Atlantic coasts, subtropical NE Atlantic (Madeira and Canary Islands), and other sequences from Rio de Janeiro in Brazil and Japan (Fig. 2).

Our sequencing effort also yielded a new ITS sequence of Ostreopsis cf. ovata from a Brazilian strain. The ITS marker seems to have a greater resolving power because the sequences of Ostreopsis ovata split into five clades. Two sequences from Japan (AB674909) and Korea (HE793379) branched in the most basal clade. The rest of sequences branched into two sister clades and each further subdividing into two subclades. Our new ITS sequence also branched in a clade with sequences of strains from the Mediterranean Sea, European Atlantic, subtropical NE Atlantic, other sequences from Brazil at Rio de Janeiro, and a few sequences from Japan (Fig. 3). Its sister subclade contained two sequences from the NE subtropical Atlantic at Madeira Island (FM244642) and the Mediterranean Sea at Greece (FM244736). The other clade was also divided into two subclades with sequences of strains isolated from Malaysia, Indonesia and Oceania at Cook Islands (Fig. 3).

\section{DISCUSSION}

Our results provide the first description of the morphology and tabulation of Ostreopsis from the South Atlantic Ocean and southernmost documented record in the Atlantic Ocean. Additionally, with new molecular data that so far, was restricted to Rio de Janeiro, Brazil
(Penna et al., 2005, 2010; Nascimento et al., 2012a). The type locality of O. ovata is the Ryukyu Islands, near Okinawa, Japan (Fukuyo, 1981), and sequences of the strains from the NW Pacific Ocean under the name $O$. ovata branched into several clades (Sato et al., 2011). The size measurement of Ostreopsis cf. ovata from Brazil ranged between the cells measured from other ocean regions. The presence of sequences from Japanese strains within the Atlantic-Mediterranean clade does not allow establishing a clear geographical pattern in the populations. Our LSU rDNA and ITS sequence did not show significant differences with other strains from Rio de Janeiro in Brazil, the Mediterranean-Atlantic region and Japan. The slight differences between the strains isolated from the same place such as those from Rio de Janeiro could be even attributed to intragenomic variability as found in other lineages of dinoflagellates (e.g. Miranda, Zhang, Zhuang, \& Lin, 2012; Wang, Zhuang, Zhang, Lin, \& Lin, 2014). Hariganeya et al. (2013) estimated an average number of 24000 copies of the LSU rDNA gene per cell in a strain of $O$. cf. ovata. In Ostreopsis, the ITS marker revealed a greater genetic distance between the strains.

Considering biogeography, Coolia and Ostreopsis are two morphologically and ecologically related genera. Ostreopsis cf. ovata and Coolia malayensis Leaw, P.-T. Lim \& Usup are the most common and widespread species of their respective genera (Penna et al., 2010). Coolia malayensis and Ostreopsis cf. ovata co-exist in our sampling area (Gómez, Qiu, Otero-Morales, Lopes, \& Lin, 2016). Consequently, we can expect that both species are able to adapt to similar environments and have similar physiological requirements. Based on the molecular data, Ostreopsis cf. ovata is commonly reported in the Mediterranean Sea, while up to date sequences of $C$. malayensis has not been reported from the Mediterranean basin. While Ostreopsis cf. ovata and C. malayensis co-exist in Brazil, these taxa do not overlay in other ocean regions. Coolia malayensis is known to occur in the Caribbean Sea (David, Laza-Martínez, Miguel, \& Orive, 2014; Gómez 


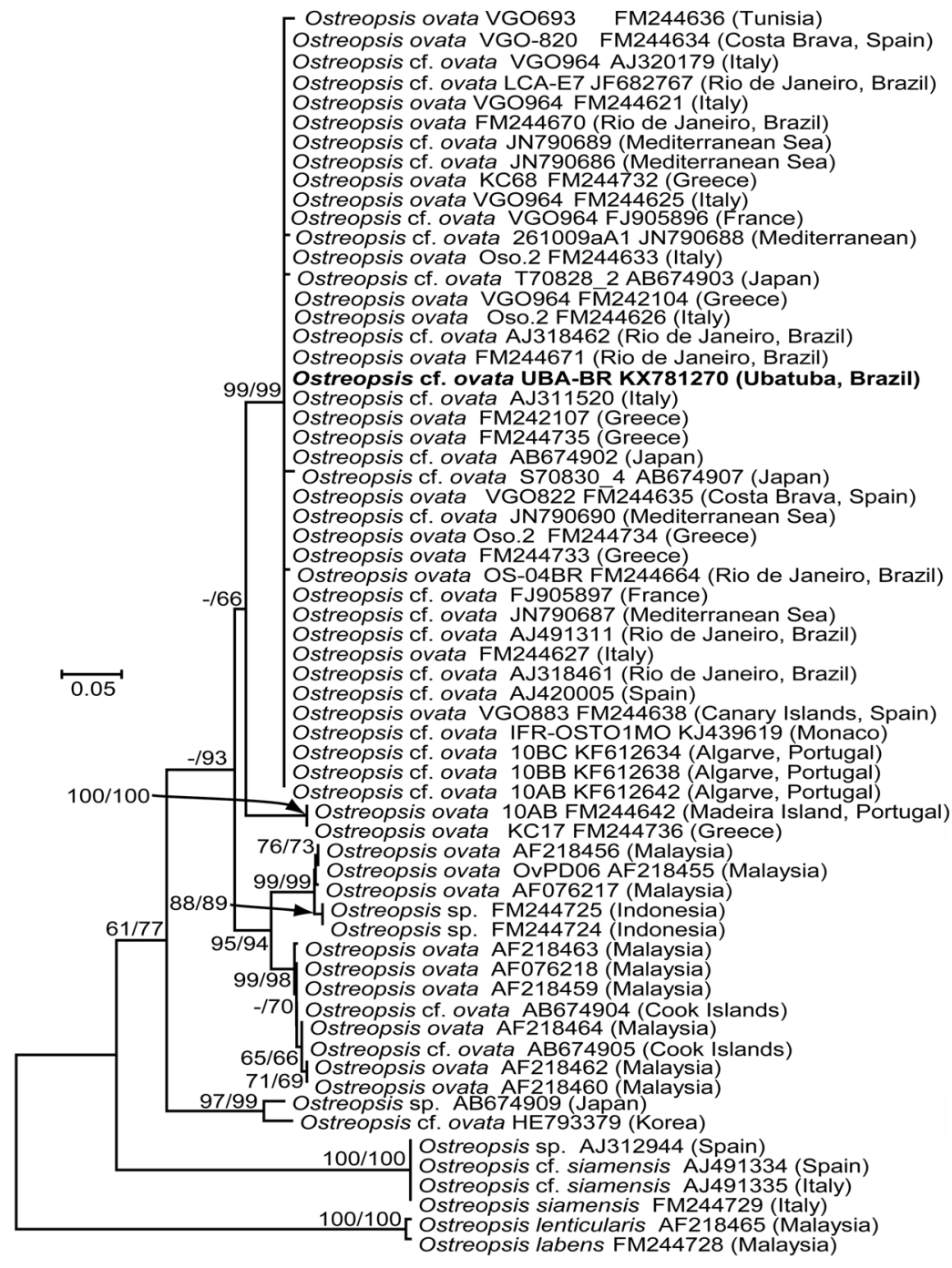

Fig. 3. Maximum likelihood tree of Ostreopsis spp. based on the ITS1-5.8S-ITS2 sequences. The sequence obtained in this study is bold-typed. Support of nodes is based on bootstrap values of Maximum Likelihood (ML)/Neighbor Joining (NJ) methods with 1000 resamplings. Only values greater than 60 are shown.

et al., 2016). Yet although Ostreopsis cf. ovata is cited in the Caribbean Sea (Tindall, Miller, \& Tindall, 1990; Gamboa-Márquez, SánchezSuárez, \& La Barbera-Sánchez, 1994), there are not sequences available from this area or the NW Atlantic Ocean. Within this context, it is not easy to infer the factors that determine their geographical distributions. It is clear that further studies with broader sampling of different geographic strains are required to understand the biogeography and population differentiation in these epiphytic dinoflagellates.

\section{ACKNOWLEDGMENTS}

This research was supported by the Brazilian Conselho Nacional de Desenvolvimento Científico e Tecnológico (grant numbers BJT 370646/2013-14 to F.G., and 402759/2012-5 and 311936/2013-0 to R.M.L.), and United 
States National Science Foundation grant (EF0629624 to S.L.). We thank the Reviewers for constructive criticisms and valuable comments.

\section{RESUMEN}

Caracterización morfológica y molecular del dinoflagelado tóxico Ostreopsis cf. ovata (Gonyaulacales: Dinophyceae) en Brasil (Océano Atlántico Sur). Ostreopsis cf. ovata es un dinoflagelado tóxico epifítico de amplia distribución en aguas cálidas, que a menudo coincide con especies de los géneros Coolia, Fukuyoa, Gambierdiscus y Prorocentrum. Investigamos una cepa aislada en la costa de Ubatuba, Brasil (Atlántico sudoccidental) mediante microscopía óptica y de epifluorescencia. Obtuvimos una secuencia de una región de unos 1900 pares de bases del cistrón del gen del ARN ribosómico. Las células tenían 35-65 $\mu \mathrm{m}$ de diámetro dorso-ventral y 20-40 $\mu \mathrm{m}$ de ancho. En la filogenia del marcador LSU rADN, las secuencias con los nombres $O$. ovata and $O$. cf. ovata se sitúan en tres grupos. El marcador ITS mostraba un mayor poder resolutivo y las secuencias de $O$. ovata/O. cf. ovata se separan en cinco grupos. Nuestra secuencia ITS se sitúa en un grupo con secuencias de cepas procedentes del Mar Mediterráneo, costas europeas Atlánticas, Atlántico subtropical nororiental, otras secuencias procedentes de Río de Janeiro en Brasil, y algunas secuencias de Japón. Las dimensiones celulares y la disposición de las placas tecales se sitúan en el rango de variabilidad descrito en otras regiones oceánicas. Nuestras observaciones confirman a $O$. cf. ovata como la especie más comúnmente registrada de Ostreopsis en el Atlántico sudoccidental. Ostreopsis cf. ovata coindice con Coolia malayensis en Brasil y Asia. Ostreopsis cf. ovata ha sido comúnmente encontrada en el Mar Mediterráneo, donde C. malayensis aún no ha sido registrada. Coolia malayensis has sido registrada en el Mar Caribe, donde O. ovata aún no ha sido encontrada. Es difícil comprender los factores que determinan la biogeografía de los dinoflagelados epífitos tropicales, a partir del conocimiento actual.

Palabras clave: Atlántico Sur, Dinofita béntica, dinoflagellata tóxica, proliferación algal dañina, mareas rojas, microalga epífita.

\section{REFERENCES}

Accoroni, S., Romagnoli, T., Penna, A., Capellacci, S., Ciminiello, P., Dell'Aversano, C., Tartaglione, L., Abboud-Abi Saab, M., Giussani, V., Asnaghi, V., Chiantore, M., \& Totti, C. (2017). Ostreopsis fattorussoi sp. nov. (Dinophyceae), a new benthic toxic Ostreopsis species from the eastern Mediterranean Sea. Journal of Phycology, doi: 10.1111/jpy.12464
Accoroni, S., Romagnoli, T., Pichierri, S., Colombo, F., \& Totti, C. (2012). Morphometric analysis of Ostreopsis cf. ovata cells in relation to environmental conditions and bloom phases. Harmful Algae, 19, 15-22.

Aligizaki, K., \& Nikolaidis, G. (2006). The presence of the potentially toxic genera Ostreopsis and Coolia (Dinophyceae) in the North Aegean Sea, Greece. Harmful Algae, 5, 717-730.

Al-Yamani, F. Y., \& Saburova, M. A. (2010). Illustrated Guide on the Flagellates of Kuwait's Intertidal Soft Sediments. Kuwait: Kuwait Institute for Scientific Research.

Ashton, M., Tosteson, T., \& Tosteson, C. (2003). The effect of elevated temperature on the toxicity of the laboratory cultured dinoflagellate Ostreopsis lenticularis (Dinophyceae). Revista de Biología Tropical, 51(Suppl. 4), 1-6.

Carnicer, O., Guallar, C., Andree, K. B., Diogène, J., \& Fernández-Tejedor, M. (2015). Ostreopsis cf. ovata dynamics in the NW Mediterranean Sea in relation to biotic and abiotic factors. Environmental Research, 143, 89-99.

Chang, F. H., Shimizu, Y., Hay, B., Stewart, R., Mackay, G., \& Tasker, R. (2000). Three recently recorded Ostreopsis spp. (Dinophyceae) in New Zealand: temporal and regional distribution in the upper North Island from 1995 to 1997. New Zealand Journal of Marine and Freshwater Research, 34(1), 29-39.

David, H., Laza-Martínez, A., Miguel, I., \& Orive, E. (2013). Ostreopsis cf. siamensis and Ostreopsis cf. ovata from the Atlantic Iberian Peninsula: Morphological and phylogenetic characterization. Harmful Algae, 30, 44-55.

David, H., Laza-Martínez, A., Miguel, I., \& Orive, E. (2014). Broad distribution of Coolia monotis and restricted distribution of Coolia cf. canariensis (Dinophyceae) on the Atlantic coast of the Iberian Peninsula. Phycologia, 53(4), 342-352.

Delgado, G., Lechuga-Devéze, C. H., Popowski, G., Troccoli, L., \& Salinas, C. A. (2006). Epiphytic dinoflagellates associated with ciguatera in the northwestern coast of Cuba. Revista de Biología Tropical, 54(2), 299-310.

Faust, M. A. (1999). Three new Ostreopsis species (Dinophyceae): O. marinus sp. nov., O. belizeanus sp. nov., and O. caribbeanus sp. nov. Phycologia, 38(2), 92-99.

Faust, M. A., \& Morton, S. L. (1995). Morphology and ecology of the marine dinoflagellate Ostreopsis labens sp. nov. (Dinophyceae). Journal of Phycology, 31(3), 456-463.

Fukuyo, Y. (1981). Taxonomical study on benthic dinoflagellates collected in coral reefs. Bulletin of the Japanese Society of Scientific Fisheries, 47(8), 967-978. 
Gamboa-Márquez, J. F., Sánchez-Suárez, I. G., \& La Barbera-Sánchez, A. (1994). Dinoflagelados (Pyrrophyta) del Archipiélago Los Roques (Venezuela): Familias Prorocentraceae y Ostreopsidaceae. Acta Cientifica Venezolana, 45(2), 140-152.

Gómez, F., Qiu, D., Lopes, R. M., \& Lin, S. (2015). Fukuyoa paulensis gen. et sp. nov., a new genus for the globular species of the dinoflagellate Gambierdiscus (Dinophyceae). PLoS ONE, 10(4), e0119676.

Gómez, F., Qiu, D., Otero-Morales, E., Lopes, R. M., \& Lin, S. (2016). Circumtropical distribution of the epiphytic dinoflagellate Coolia malayensis (Dinophyceae): Morphology and molecular phylogeny from Puerto Rico and Brazil. Phycological Research, 64(3), 194-199.

Hariganeya, N., Tanimoto, Y., Yamaguchi, H., Nishimura, T., Tawong, W., Sakanari, H. Yoshimatsu, T., Sato, S., Preston, C. M., \& Adachi, M. (2013). Quantitative PCR method for enumeration of cells of cryptic species of the toxic marine dinoflagellate Ostreopsis spp. in coastal waters of Japan. PLoS ONE, 8(3), e57627.

Hernández-Becerril, D. U. \& Almazán Becerril, A. (2004). Especies de dinoflagelados del género Gambierdiscus (Dinophyceae) del Mar Caribe mexicano. Revista de Biología Tropical, 52(Suppl. 1), 77-87.

Larkin, M. A., Blackshields, G., Brown, N. P., Chenna, R., McGettigan, P. A., McWilliam, H., Valentin, F., Wallace, I. M., Wilm, A., López, R., Thompson, J .D., Gibson, T. J., \& Higgins, D. G. (2007). CLUSTALW and CLUSTALX version 2.0. Bioinformatics, 23(21), 2947-2948

Larsen, J., \& Nguyen, N. L. (2004). Potentially toxic microalgae of Vietnamese waters. Opera Botanica, $140,5-216$.

Leaw, C. P., Lim, P. T., Ahmad, A., \& Usup, G. (2001). Genetic diversity of Ostreopsis ovata (Dinophyceae) from Malaysia. Marine Biotechnology, 3(3), 246-255.

Monti, M., Minocci, M., Beron, A., \& Ivesa, L. (2007). First record of Ostreopsis cf. ovata on macroalgae in the Northern Adriatic Sea. Marine Pollution Bulletin, 54(5), 598-601.

Miranda, L. N., Zhang, H., Zhuang, Y., \& Lin, S. (2012). Phylogenetic analysis guided by intragenomic SSU rDNA polymorphism refines classification of "Alexandrium tamarense" species complex. Harmful Algae, 16, 35-48.

Nascimento, S. M., Corrêa, E. V., Menezes, M., Varela, D., Paredes, J., \& Morris, S. (2012a). Growth and toxin profile of Ostreopsis cf. ovata (Dinophyta) from Rio de Janeiro, Brazil. Harmful Algae, 13, 1-9.

Nascimento, S. M., França, J. V., Gonçalves, J. E. A., \& Ferreira, C. E. L. (2012b). Ostreopsis cf. ovata (Dinophyta) bloom in an equatorial island of the Atlantic Ocean. Marine Pollution Bulletin, 64(5), 1074-1078.

Norris, D. R., Bomber, J. W., \& Balech, E. (1985). Benthic dinoflagellates associated with ciguatera from the Florida Keys. I. Ostreopsis heptagona sp. nov. In D. M. Anderson, A. W. White, \& D. G. Baden (Eds.), Toxic Dinoflagellates (pp. 39-44). New York: Elsevier.

Parsons, M. L., Aligizaki, K., Dechraoui, M. Y., Fraga, S., Morton, S., Penna, A., \& Rhodes, L. (2012). Gambierdiscus and Ostreopsis: reassessment of the state of knowledge of their taxonomy, geography, ecophysiology, and toxicology. Harmful Algae, 14, 107-129.

Penna, A., Fraga, S., Battocchi, C., Casabianca, S., Riobó, P., Giacobbe, M. G., \& Vernesi, C. (2010). A phylogeography study of the toxic benthic dinoflagellate genus Ostreopsis Schmidt. Journal of Biogeography, 37(5), 830-841.

Penna, A., Vila, M., Fraga, S., Giacobbe, M. G., Andreoni, F., Riobó, P., \& Vernesi, C. (2005). Characterization of Ostreopsis and Coolia (Dinophyceae) isolates in the western Mediterranean Sea based on morphology, toxicity and internal transcribed spacer 5.8S rDNA sequences. Journal of Phycology, 41(1), 212-225.

Posada, D., \& Crandall, K. A. (1998). MODELTEST: testing the model of DNA substitution. Bioinformatics, 14(9), 817-818.

Qiu, D., Huang, L., Liu, S., \& Lin, S. (2011). Nuclear, mitochondrial and plastid gene phylogenies of Dinophysis miles (Dinophyceae): Evidence of variable types of chloroplasts. PLOS ONE, 6(12), e29398.

Qiu, D., Huang, L., Liu, S., Zhang, H., \& Lin, S. (2013). Apical groove type and molecular phylogeny suggests reclassification of Cochlodinium geminatum as Polykrikos geminatum. PLoS ONE, 8(8), e 71346.

Quod, J. P. (1994). Ostreopsis mascarenensis sp. nov. (Dinophyceae), dinoflagellé toxique associé à la ciguatera dans l'Océan Indien. Cryptogamie Algologie, 15(4), 243-251.

Rossi, R., Castellano, V., Scalco, E., Serpe, L., Zingone, A., \& Soprano, V. (2010). New palytoxin-like molecules in Mediterranean Ostreopsis cf. ovata (dinoflagellates) and in Palythoa tuberculosa detected by liquid chromatography-electrospray ionization time-offlight mass spectrometry. Toxicon, 56(8), 1381-1387.

Sato, S., Nishimura, T., Uehara, K., Sakanari, H., Tawong, W., Hariganeya, N., Smith, K., Rhodes, L., Yasumoto, T., Taira, Y., Suda, S., Yamaguchi, H., \& Adachi, M. (2011). Phylogeography of Ostreopsis along west Pacific coast, with special reference to a novel clade from Japan. PLoS ONE, 6(12), e27983. 
Scalco, E., Brunet, C., Marino, F., Rossi, R., Soprano, V., Zingone, A., \& Montresor, M. (2012). Growth and toxicity responses of Mediterranean Ostreopsis cf. ovata to seasonal irradiance and temperature conditions. Harmful Algae, 17, 25-34.

Schmidt, J. (1901). Flora of Koh Chang. Contributions to the knowledge of the vegetation in the Gulf of Siam. Peridiniales. Botanisk Tidsskrift, 24, 212-221.

Selina, M. S., \& Levchenko, E. V. (2011). Species composition and morphology of Dinoflagellates (Dinophyta) of epiphytic assemblages of Peter the Great Bay in the Sea of Japan. Russian Journal of Marine Biology, 37(1), 23-32.

Tamura, K., Stecher, G., Peterson, D., Filipski, A., \& Kumar, S. (2013). MEGA6: Molecular Evolutionary Genetics Analysis version 6.0. Molecular Biology and Evolution, 30(12), 2725-2729.
Tindall, D. R., Miller, D. M., \& Tindall, P. M. (1990). Toxicity of Ostreopsis lenticularis from the British and United States Virgin Islands. In E. Granéli, B. Sundstrom, L. Edler \& D. M. Anderson (Eds.), Toxic Marine Phytoplankton (pp. 424-429). New York: Elsevier.

Tognetto, L., Bellato, S., Moro, I., \& Andreoli, C. (1995). Occurrence of Ostreopsis ovata (Dinophyceae) in the Tyrrhenian Sea during summer 1994. Botanica Marina, 38, 291-295.

Tosteson, T. R. (2004). Caribbean ciguatera: a changing paradigm. Revista de Biología Tropical, 52(Suppl. 1), 109-113.

Wang, L., Zhuang, Y., Zhang, H., Lin, X., \& Lin, S. (2014). DNA barcoding species in Alexandrium tamarense complex using ITS and proposing designation of five species. Harmful Algae, 31, 100-113. 